\title{
PENGEMBANGAN PERANGKAT PEMBELAJARAN BERBASIS MODEL PBL SUBTEMA LINGKUNGAN TEMPAT TINGGALKU DALAM MENINGKATKAN HASIL BELAJAR SISWA KELAS IV SEKOLAH DASAR
}

\author{
Habibatul Imamah \\ Pendidikan Dasar Pascasarjana Universitas Negeri Surabaya
}

\begin{abstract}
Abstrak
Tujuan penelitian ini (1) Untuk mendiskripsikan kelayakan hasil pengembangan perangkat pembelajaran berbasis model Problem Based Learning dalam meningkatkan hasil belajar pada subtema lingkungan tempat tinggalku siswa kelas IV sekolah dasar. (2) Untuk mendiskripsikan efektifitas pengembangan perangkat pembelajaran berbasis model Problem Based Learning dalam meningkatkan hasil belajar pada subtema lingkungan tempat tinggalku siswa kelas IV sekolah dasar. Penelitian ini merupakan penelitian pengembangan dengan model 4-D (define, desain, development,dessiminate).

Penelitian ini menghasilkan perangkat pembelajaran subtema lingkungan tempat tinggalku bahwa:(1) validitas silabus mendapat skor rata-rata 3,5 dengan kategori baik. (2) hasil validitas RPP mendapat skor rata-rata 3,8 kategori baik. (3) hasil validitas LKS mendapat skor rata-rata 3,9 kategori baik (4) hasil validitas Buku ajar mendapatkan skor rata-rata 3,6 dengan kategori baik (5) hasil validitas THB mendapatkan skor rata-rata 3,85 dengan kategori baik. (6) hasil pengamatan keterlaksanaan pembelajaran mendapat skor yang dipersentase $93 \%$ dalam kategori baik . (7) berdasarkan hasil posttest hasil belajar siswa kelas eksperimen dan kelas control dapat dilihat pada angkat t-test yang mengasumsikan kedua populasi sama adalah 10,341 dengan probabbilitas (sig) sebesar 0,000. Oleh karena itu angka probabilitas $<0,05$, dapat diartikan adanya perbedaan antara nilai yang diperoleh kelas eksperimen dan kelas control. Dengan demikian dapat disimpulkan bahwa model PBL dapat meningkatkan hasil belajar siswa atau efektif diterapkan pada pembelajaran subtema lingkungan tempat tinggalku
\end{abstract}

Kata Kunci : Perangkat Pembelajaran, PBL, Hasil Belajar

\begin{abstract}
This research can be classified as development research because in this research learning instrument is developed. Formula of problem in this research is (1) What is result feasibility of learning instrument development based on problem based learning (PBL) in improving learning outcomes on subtopic of "environment where I live" students grade four; (2) What is effectiveness of learning instrument development based on problem based learning (PBL) in improving learning outcomes on subtopic of "environment where I live" students grade four. This development research is based on $4 D$ model which consist of (1) definition, (2) design, (3) development, and (4) distribution. However, this research only reaches stage of development without conducting stage of distribution. The developed learning instrument consists of syllabus, lesson plan, student worksheet, learning outcomes test and student book.

Design of this research uses pretest-posttest control group design are as follows: (1) validity of syllabus obtains mean score of 3.5 which is good category; (2) validity of lesson plan results in mean score of 3,8 which is good category; (3) validity of student worksheet results in mean score of 3.9 which is good category; (4) validity of textbook results in mean score of 3.6 which is good category; (5) validity of learning outcomes test results in mean score of 3.85 which is good category; (6) observation on feasibility of learning results in percentage score of 93\% which is good category; (7) based on result of learning outcomes posttest on experiment class and control class it can be seen that by assuming both population are same then score of $t$-test is 10.341 and probability (sig) is 0.000 . Due to probability $<0.05$ then it means that difference exists between score obtained by experiment class and control class. Therefore, it can be concluded that PBL model can improve students' learning outcomes or effective to apply on learning with subtopic of "environment where I live".
\end{abstract}


Based on development process and result of learning instrument validation on PBL model, this indicates good category and feasible to use. Meanwhile, based on result of learning instrumen implementation on the developed PBL model, it can be said good to support learning and teaching activities for students grade four.

Keywords: development of learning instrument, PBL, learning outcomes

\section{PENDAHULUAN}

Memasuki era globlalisasi dan seiring perkembangan ilmu pengetahuan yang semakin pesat diperlukan sumber daya manusia yang berkualitas dan berguna bagi masyarakat. Salah satu upaya yang dapat dilakukan adalah melalui peningkatan kualitas pendidikan. Pendidikan bertujuan untuk memperbaiki kualitas kehidupan dalam rangkaian pengembangan sumber daya manusia yang bermutu (Hamalik, 1994:10). Karena itulah semestinya proses pembelajaran yang baik adalah mengajarkan siswa mengahadapi masalah yang aktual dan terjadi secara langsung. pembelajaran harus diarahkan pada bagaimana membelajarkan siswa dengan menekankan proses aktif, siswa mengkonstruksikan atau membangun sendiri pengetahuannya, memposisikan siswa sebagai salah satu sumber belajar, memberi peluang siswa memanfaatkan sumber belajar secara beragam dan melakukan kolaborasi, sehingga kegiatan belajar berlangsung secara aktif dan kreatif.sejauh ini proses pembelajaran di sekolah masih didominasi oleh sebuah paradigma yang menyatakan bahwa sebuah pengetahuan merupakan perangkat fakta-fakta yang harus dihafal. Murid sebatas pendengar pasif dengan sikap diam, duduk manis mendengarkan, merekam, mencatat apa yang disampaikan oleh guru. Hal ini menyebabkan siswa kurang mendapatkan suasana akademik yang memberikan ruang kebebasan, rasa aman dan senang untuk mengekspresikan pendapat, argumen, pertanyaan-pertanyaan kritis dan berperan aktif dalam kegiatan pembelajaran. Sebagian besar siswa tidak mampu menghubungkan antara apa yang mereka pelajari dengan bagaimana pengetahuan tersebut akan dipergunakan atau dimanfaatkan. Kemampuan anak untuk bertanya dan mengemukakan pendapat juga masih kurang. Banyak siswa yang hanya menghafal prosedur tetapi tidak bisa memaknainya. Hal ini menyebabkan peserta didik kurang terlatih mengembangkan keterampilan berpikir dalam memecahkan masalah dan menerapkan konsep-konsep yang dipelajari di sekolah ke dalam dunia nyata. Kondisi inilah yang menyebabkan hasil belajar siswa rendah. Untuk meningkatkan hasil belajar pada materi kegiatan ekonomi, guru harus melakukan suatu perubahan pada proses pembelajaran, dimana proses pembelajaran tersebut dapat melatih siswa untuk belajar mandiri dan siswa dapat berinteraksi secara langsung dengan lingkungan sekitar. Perubahan pada pembelajaran tersebut dapat dilakukan guru dengan cara memilih model yang tepat untuk materi yang diajarkan. Model pembelajaran yang dapat meningkatkan motivasi siswa dalam belajar, melatih siswa untuk dapat belajar mandiri, dan melibatkan siswa untuk berperan aktif dalam pembelajaran, sehingga pembelajaran akan lebih bermakna dalam diri siswa dan siswa dapat mengaplikasikannya dalam kehidupan nyata. Selain itu, melalui model pembelajaran guru dapat membantu peserta didik mendapatkan informasi, ide, keterampilan, cara berpikir, dan mengekspresikan ide. Salah satu model pembelajaran yang menunjang keterlibatan siswa dalam kegiatan belajar mengajar adalah Model Problem Based learning (PBL). PBL dapat menjadi salah satu alternative untuk meningkatkan kualitas pembelajaran. PBL merupakan suatu strategi yang dimulai dengan menghadapkan siswa pada masalah sehari-hari. PBL menuntut adanya peran aktif siswa agar dapat mencapai pada penyelesaian masalah yang diharapkan sesuai dengan tujuan pembelajaran. Agar guru dapat melakukan pembelajaran PBL dengan baik, diperlukan perangkat pembelajaran yang baik. Karena perangkat pembelajaran merupakan modal yang bisa digunakan guru sebagai pedoman dalam melaksanakan pembelajaran di kelas.

Menurut Arends (dalam Trianto, 2007: 68), PBL merupakan suatu pendekatan pembelajaran dimana siswa mengerjakan permasalahan yang autentik dengan maksud untuk menyusun 
pengetahuan mereka sendiri, lebih tinggi, mengembangkan kemandirian dan percaya diri.

Sedangkan menurut Trianto (2007: 67), model PBL merupakan suatu model pembelajaran yang didasarkan pada banyaknya permasalahan yang membutuhkan penyelidikan autentik yakni penyelidikan yang membutuhkan penyelesaian nyata dari permasalahan yang nyata.

Menurut Nana Sudjana (2009: 3), hasil belajar siswa pada hakikatnya adalah perubahan tingkah laku sebagai hasil belajar dalam pengertian yang lebih luas mencakup bidang kognitif, afektif, dan psikomotorik.

Menurut Syaiful Bahri Djamarah (1996:23) mengenai hasil belajar adalah hasil yang diperoleh berupa kesan-kesan yang mengakibatkan perubahan dalam diri individu sebagai hasil dari aktivitas dalam belajar. Sistem pendidikan nasional dan rumusan tujuan pendidikan baik tujuan kurikuler maupun tujuan instruksional pada umumnya menggunakan klasifikasi hasil belajar Bloom yang secara garis besar membaginya menjadi tiga ranah, ranah kognitif, afektif, dan psikomotoris. Ranah kognitif berkenaan dengan hasil belajar intelektual yang terdiri dari enam aspek, yakni: knowledge (pengetahuan), comprehension (pemahaman), aplikasi, analisis, sintesis, dan evaluasi. Kedua aspek pertama disebut kognitif tingkat rendah dan keempat aspek berikutnya termasuk kognitif tingkat tinggi. Ranah afektif berkenaan dengan sikap yang terdiri dari lima aspek, yakni: penerimaan, jawaban atau reaksi, penilaian, organisasi, dan internalisasi. Ranah psikomotoris berkenaan dengan hasil belajar keterampilan dan kemampuan bertindak yang terdiri atas enam aspek, yakni: gerakan refleks, keterampilan gerakan dasar, kemampuan perseptual, keharmonisan atau ketepatan, gerakan keterampilan kompleks, dan gerakan ekspresif dan interpretatif (Sudjana, 2005).

Dari uraian di atas dapat disimpulkan bahwa hasil belajar adalah perubahan pada kognitif, afektif dan psikomotorik sebagai pengaruh pengalaman belajar yang dialami siswa baik berupa suatu bagian, unit, atau bab materi tertentu yang telah diajarkan. Dalam penelitian ini aspek yang di ukur adalah perubahan pada tingkat kognitifnya saja.

\section{Metode Penelitian}

Rancangan uji coba yang akan dilaksanakan adalah menggunakan teknik pretest-posttest control group design. Rancangan penelitian ini dimulai dengan melakukan pretest sebagai uji awal untuk mengetahui konsep awal siswa, selanjutnya dikenakan perlakuan dalam jangka waktu tertentu, kemudian dilakukan posttest sebagai uji akhir untuk mengetahui tingkat kemampuan siswa untuk mengikuti pembelajaran pada sub tema lingkungan tempat tinggalku .

Rancangan penelitian digambarkan sebagai berikut.

\begin{tabular}{|llll|}
\hline E & O1 & X & O2 \\
C & O3 & - & O4 \\
\hline
\end{tabular}

Keterangan:

01 :pretest pada kelompok eksperimen

$\mathbf{O 2}$ :posttest pada kelompok eksperimen

$\mathbf{0 3}$ :pretest pada kelompok control

04 :posttest pada kelompok control

E:subyek penelitian kelompok eksperimen

C:subjek penelitian kelompok control

$\mathbf{X}$ :treatment dengan menggunakan perangkat pada kelompok eksperimen. (Sugiyono, 2007: 112).

\section{Analisis Tes Hasil Belajar}

Untuk memperoleh data hasil belajar dari nilai pretest dan postest, skor hasil penilaian tes dianalisis menggunakan rumus (Asep dalam Oktaviana, 2011) berikut ini:

$$
\text { Nilai }=\frac{\text { skor } \text { yang diperoleh }}{\text { skor maksimal }} \times 100
$$

Untuk mengetahui perbedaan hasil belajar siswa menggunakan perangkat pembelajaran PBL pada kelas IV A dan kelas IV B yang tidak menggunakan perangkat pembelajaran PBL. Dianalisis menggunakan uji $t$ berpasangan (related/paired) dengan syarat data homogen. Melalui operasi komputerisasi data uji t dapat dianalisis menggunakan softwere SPSS.

\section{Hasil Penelitian}

Alat evaluasi untuk mengukur pengetahuan siswa dengan menggunakan tes hasil belajar. THB dikembangkan dalam bentuk soal uraian yang mengacu padda taxonomi Bloom. Soal THB terdiri dari 5 soal yang berkaitan dengan sub tema lingkungan tempat tinggalku. Adapun hasil validasi perangkat tes hasil belajar dari pakar dapat dilihat pada tabel 4.6 
Tabel 4.6 Data Penilaian Tes Hasil

\begin{tabular}{|c|c|c|c|c|c|c|}
\hline \multirow{2}{*}{$\begin{array}{c}\text { Ben- } \\
\text { tuk } \\
\text { soal }\end{array}$} & \multirow[b]{2}{*}{$\begin{array}{c}\text { No } \\
\text { So- } \\
\text { al }\end{array}$} & \multicolumn{2}{|c|}{ Validator 1} & \multicolumn{2}{|c|}{ Validator 2} & \multirow[b]{2}{*}{$\begin{array}{l}\text { Skor } \\
\text { total }\end{array}$} \\
\hline & & $\begin{array}{c}\text { As- } \\
\text { pek } \\
1\end{array}$ & $\begin{array}{c}\text { As- } \\
\text { pek } \\
2\end{array}$ & $\begin{array}{c}\text { As- } \\
\text { pek } \\
1\end{array}$ & $\begin{array}{c}\text { As- } \\
\text { pek } \\
2\end{array}$ & \\
\hline \multirow{5}{*}{$\begin{array}{c}\text { Urai- } \\
\text { an }\end{array}$} & 1 & 4 & 4 & 3 & 4 & 3,75 \\
\hline & 2 & 4 & 4 & 4 & 4 & 4 \\
\hline & 3 & 4 & 4 & 4 & 3 & 3,75 \\
\hline & 4 & 4 & 4 & 4 & 4 & 4 \\
\hline & 5 & 4 & 4 & 4 & 3 & 3,75 \\
\hline \multicolumn{6}{|c|}{ Skor total } & 30,75 \\
\hline \multicolumn{6}{|c|}{ Rata-rata } & 3,85 \\
\hline \multicolumn{6}{|c|}{ Kriteria } & Valid \\
\hline
\end{tabular}

Berdasarkan Tabel 4.6 tersebut memperlihatkan bahwa tes mendapatkan skor rata-rata 3,85 . Berdasarkan koefisien validitas perangkat ajar, maka tes hasil belajar yang telah dikembangkan peneliti dapat digunakan sebagai perangkat pembelajaran.

\section{Uji Reliabilitas.}

Butir soal yang sudah dinyatakan valid oleh dosen ahli, selanjutnya diuji tingkat reliabilitasnya. Reliabilitas menunjukkan tingkat keajegan atau keandalan instrument dalam menjalankan fungsinya sebagai alat ukur. Taraf reliabilitas suatu tes dinyatakan dalam suatu angka koefisien reliabilitas. Berikut hasil perhitungan reliabilitas tes dengan menggunakan program SPSS.

Tabel 4.7. Uji Reliabilitas Soal Tes Hasil Belajar

\section{Reliability Statistics}

\begin{tabular}{|l|l|}
\hline Cronbach's Alpha & N of Items \\
\hline 0.604 & 5 \\
\hline
\end{tabular}

Dari hasil perhitungan reliabilitas soal tes hasil belajar diperoleh nilai $\mathrm{r}$ sebesar $=0,604$. Berdasarkan koefisien reliabilitas maka soal tes kemampuan berpikir kreatif yang diuji cobakan tergolong reliabilitas cukup. Jadi dapat disimpulkan bahwa soal tes hasil belajar bisa digunakan pada uji sesungguhnya.

$$
\text { Uji Hasil Belajar Pretes }
$$
Uji homogenitas pretes dalam penelitian ini dilaksanakan untuk mengetahui suatu kelompok tersebut memiliki varians kelompok yang homogen

atau tidak. Dalam penelitian ini untuk menguji kesamaan varians digunakan program SPS

Tabel 4.14 Homoginitas Hasil Belajar Pretest kelas Eksperimen dan Kelas control Group Statistics

\begin{tabular}{|rl|r|r|r|r|}
\hline & Grip & \multicolumn{1}{|c|}{ N } & Mean & Std. Deviation & Std. Eror Mean \\
\hline Pretest & Eksperimen & 37 & 74.11 & 6.673 & 1.083 \\
& Control & 33 & 73.55 & 7.637 & 1.239 \\
\hline
\end{tabular}

Tabel 4.15

Independent Samples Test

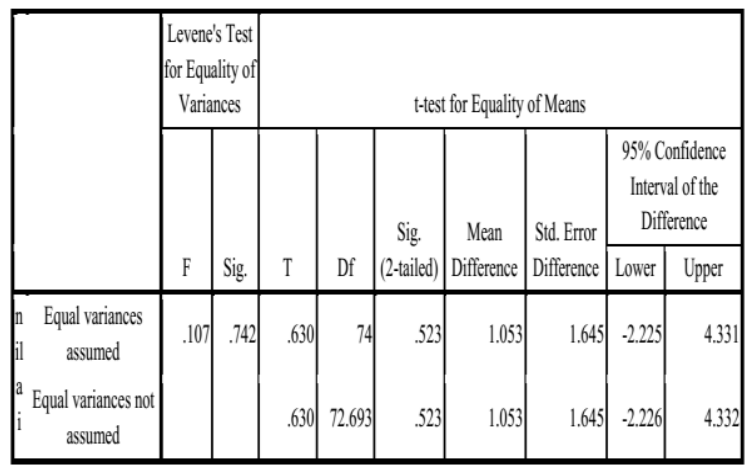

Berdasarkan tabel di atas dapat dilihat pada angka $\mathrm{F}$ yang mengasumsikan kedua varian sama adalah 0,107 dengan signifikansi 0,742. Karena angka signifikasi $>0,05$ maka dapat disimpulkan bahwa varians sampel adalah homogen Kedua kelas mengasumsikan sama pada hasil t-tes yaitu 0,630 dengan probabilitas ( $\mathrm{sig}$ ) sebesar 0,523. Oleh karena itu angka probabilitas $>0,05$, maka dapat diartikan tidak ada perbedaan secara signifikan 1. Uji Hasil Belajar Postest Untuk menguji perbedaan tes hasil belajar postest pretest kelas eksperimen dan pretest kelas kontrol, digunakan uji paired sampel t-tes dimana hasil paired sampel $\mathrm{t}$ dapat disajikan pada 4.14

Uji Homoginitas Hasil Belajar Postest kelas Eksperimen dan Kelas kontrol Group Statistics

\begin{tabular}{|rc|r|r|r|r|}
\hline & Group & \multicolumn{1}{|c|}{ N } & \multicolumn{1}{c|}{ Mean } & \multicolumn{1}{c|}{ Std. Deviation } & \multicolumn{1}{|c|}{ Std. Error Mean } \\
\hline Posttest & Eksperimen & 25 & 87.84 & 5.352 & 1.070 \\
& Control & 25 & 73.44 & 4.454 & .891 \\
\hline
\end{tabular}


Tabel 4.15

Independent Samples Test

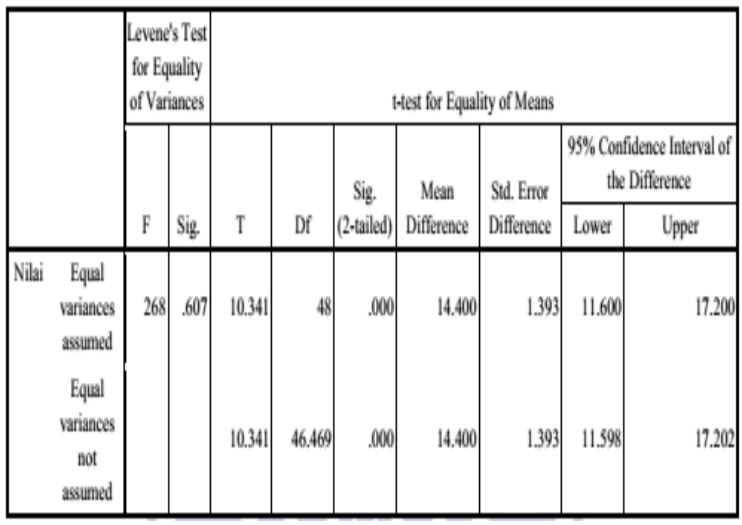

Berdasarkan tabel 4.15 dapat diketahui kesamaan varian dapat dilihat pada angka $\mathrm{F}$ yang mengasumsikan kedua varian sama adalah 268 dengan probabilitas (sig) sebesar 0,607. Oleh karena itu angka probabilitas $>0,05$, berarti tidak ada perbedaan antara kelas eksperimen dan kelas kontrol pada tes hasil belajar.

Untuk mengetahui perbandingan posttest hasil belajar kelas eksperimen dan kelas kontrol dapat dilihat pada angka t-test yang mengasumsikan kedua populasi sama adalah 10.341 dengan probabbilitas (sig) sebesar 0,000 . Oleh karena itu angka probabilitas $<0,05$, dapat diartikan adanya perbedaan antara nilai yang diperoleh kelas eksperimen dan kelas kontrol. Sehingga dapat disimpulkan, bahwa terdapat perbedaan hasil belajar anatar kelompok eksperimen dan kelompok kontrol

Berdasarkan Tabel 4.12 diperoleh rata-rata skor postes hasil belajar kelompok eksperimen adalah 87,84 sedangkan rata-rata skor postes hasil belajar kelompok kontrol adalah 73,44. Kedua rata-rata tersebut cukup berbeda sehingga tes hasil belajar kelompok eksperimen lebih tinggi.

Jadi dalam penelitian ini dapat disimpulkan bahwa hasil belajar siswa yang menggunakan PBL lebih tinggi secara signifikan dibanding dengan hasil belajar siswa yang tidak menggunakan model PBL.

\section{Diskusi Hasil Penelitian}

Hasil belajar diperoleh dari test hasil belajar siswa yang dilakukan sebanyak tiga kali pertemuan, yaitu tes awal (pretest) untuk mengetahui kemampuan awal siswa sebelum diberikan perlakuan dan test akhir (postest) setelah diberikan perlakuan, untuk mengetahui hasil belajar dengan menggunakan model PBL. Kreteria ketuntasan minimal MI Bahrul Ulum $\geq 75$, jadi siswa dianggap tuntas dan meningkat hasil belajarnya jika mencapai 75 .

Hasil belajar subtema lingkungan tempat tinggalku meliputi materi (1) letak geografis (2) kegiatan ekonomi (3) sember daya alam. Berdasarkan data yang diperoleh dari analisis tes hasil belajar terjadi peningkatan subtema lingkungan tempat tinggalku pada kelas yang menggunakan model PBL terutama pada materi kegiatan ekonomi. Sedangkan peningkatan terendah ada pada materi kondisi geografis.dari hasil analisis dapat disimpulkan bahwa model PBL sesuai digunakan untuk subtema lingkungan tempat tinggalku terutama pada materi kegiatan ekonomi.

Hasil belajar yang di ukur dalam penelitian ini adalah pada ranah kognitif yang meliputi mengingat $(\mathrm{C} 1)$, memahami (C2), menerapkan (C3), menganalisis (C4), mengevaluasi (C5), mengkreasi (C6). Berdasarkan analisis hasil belajar yang telah dilakukan terdapat peningkatan hasil belajar ranah kognitif pada kelas yang menggunakan model PBL, terutama pada level menganalisis (C4). Sedangkan peningkatan terendah adalah pada level mengkreasi (C6).

Hal ini sesuai dengan pendapat Ausubel, bahwa belajar dikatakan bermakna jika informasi yang akan dipelajari peserta didik disusun sesuai dengan struktur kognitif yang dimiliki peserta didik, sehingga peserta didik dapat mengaitkan informasi barunya dengan struktur kognitif yang dimilikinya. Dalam buku kerangka landasan untuk pembelajaran, pengajaran, dan asesmen revisi taxonomi bloom oleh Anderson krathwohl (2010:97) bahwa pembelajaran yang bermakna menghadirkan pengetahuan dan proses-proses kognitif yang siswa butuhkan untuk menyelesaikan masalah. Penyelesaian masalah terjadi ketika siswa akan merumuskan kembali masalahnya dalam bahasa yang lebih familier, mengenali bahwa masalahnya serupa dengan masalah yang sudah familier bagi mereka, mengabstrasikan solusi untuk masalah yang hendak diselesaikannya. Focus dalam pembelajaran yang telah dilakukan selama penelitian bermakna dengan mengkonstruksi 
pengetahuan siswa dengan menyelesaikan masalah yang menuntut siswa untuk berpikir sesuai tingkat kognitif $\mathrm{C} 1$ (mengingat), C2(memahami), C3(menerapkan), C4(menganalisis), C5 (mengevaluasi), C6(mengkreasi). Hal ini juga sejalan dengan pendapat dari john dewey yang menyatakan bahwa guru harus mendorong siswa terlibat dalam proyek atau tugas berorientasi masalah dan membantu mereka menyelidiki masalah-masalah intelektual dan sosial. Dasar ini sebagai pengembangan PBL. dan terbukti dari hasil penelitian siswa mampu menyelesaikan masalah begitu juga dengan pembelajaran menggunakan PBL hasil belajar siswa meningkat terutama pada tingkat kognitif level C4 (Menganalisis), hal ini membuktikan bahwa PBL sangat efektif digunakan dalam pembelajaran.

Berdasarkan tabel 4.11 dapat diketahui hasil pretest hasil belajar kelas eksperimen dan kelas control. Untuk menguji kesamaan varian dapat dilihat pada angka $\mathrm{F}$ yang mengasumsikan oleh kedua varian sama adalah 0,107 dengan probabilitas ( $\mathrm{sig}$ ) sebesar 0,742 . Oleh karena itu angka probabilitas $>0.05$, berarti tidak ada perbedaan antara kelas kesperimen dan kelas control pada tes hasil belajar. Kedua kelas mengasumsikan sama pada hasil t-tes yaitu 0,630 dengan probabilitas (sig) sebesar 0,523. Oleh karena itu angka probabilitas $>0,05$, maka dapat diartikan tidak ada perbedaan secara signifikan. Berdasarkan tabel 4.13 dapat diketahui hasil posttest hasil belajar kelas eksperimen dan kelas control Untuk menguji kesamaan varian dapat dilihat pada angka $\mathrm{F}$ yang mengasumsikan oleh kedua varian sama adalah 268 dengan probabilitas (sig) sebesar 0,607. Oleh karena itu angka probabilitas $>5 \%$, berarti tidak ada perbedaan antara kelas kesperimen dan kelas control pada tes hasil belajar. Untuk data perolehan posttest hasil belajar kelas eksperimen dan kelas control dapat dilihat pada angka t-test yang mengasumsikan kedua populasi sama adalah 10.341dengan probabbilitas (sig) sebesar 0,000. Oleh karena itu angka probabilitas $<0,05$, dapat diartikan adanya perbedaan antara nilai yang diperoleh kelas eksperimen dan kelas control. Melalui uji t-test correlated/paired kelas eksperimen dan kelas control pada tahap prestest kedua kelas mendapatkan nilai yang sama dan tidak ada perbedaan. Adapun pada kelas eksperimen diberikan perlakuan dengan model PBL sehingga pada tahap posttest mendapat perolehan nilai yang meningkat. Sehingga dapat disimpulkan, ada pengaruh pengembangan perangkat pembelajaran dengan model PBL terhadap peningkatan tes hasil belajar siswa kelas IV A MI bahrul Ulum.

\section{PENUTUP}

\section{Kesimpulan}

Berdasarkan dari hasil penelitian, maka dapat disimpulkan bahwa perangkat pembelajaran berbasis model PBL yang dikembangkan berdasarkan model 4-D sebagai berikut:

1. Dari hasil validitas pengembangan tersebut, perangkat pembelajaran berbasis model PBL dinyatakan telah valid atau memenuhi kelayakan sebagai perangkat pembelajaran pada subtema lingkungan tempat tinggalku di kelas IV. Perangkat pembelajaran berbasis PBL yang dikembangakan telah melalui beberapa tahap yaitu tahap pendefinisian, tahap perencanaan, dan tahap pengembangan.

2. Fokus dari penelitian pengembangan perangkat pembelajaran berbasis model PBL, berdasarkan hasil penelitian bahwa hasil belajar subtema lingkungan tempat tinggalku yang meliputi kondisi geografis, kegiatan ekonomi dan sumber daya alam dapat diketahui adanya peningkatan nilai pada materi kegiatan ekonomi yaitu 60\%. Hasil belajar siswa yang mengikuti pembelajaran berbasis PBL lebih tinggi dari pada hasil belajar siswa yang tidak mengikuti pembelajaran dengan model PBL terutama pada materi kegiatan ekonomi dan pada ranah kognitif level menganalisis (C4). Dengan demikian, dapat disimpulkan bahwa penerapan pembelajaran berbasis PBL pada subtema lingkungan tempat tinggalku dapat meningkatkan hasil belajar siswa kelas IV SD dan lebih sesuai untuk materi kegiatan ekonomi.

\section{DAFTAR PUSTAKA}

Akbar. (2013). Pengembangan perangkat pembelajaran. Bandung :Alfabeta. 
Amir, Taufiq. (2009). Inovasi Pendidikan Melalui Problem Based Learning. Jakarta :Kencana Prenada Media Group.

Amri, Sofan. (2011). Mengembangkan Pembelajaran IPS Terpadu. Jakarta : PT PrestasiPustakaraya.

Asrori, Muhammad. (2007). Psikologi Pembelajaran. Bandung : CV Wacana Prima.

Arzu Arı. (2013) The opinions of primary mathematics student-teachers on problembased learning methodKocaeli University: Education Faculty Primary Department

Barbara K. (2009). Implementing Problem-Based Learning in an Undergraduate Psychology Course: A Journal of Scholarly Teaching

Djamarah, Syaiful Bahri dan Aswan Zain. (2006). Strategi Belajar Mengajar. Jakarta : PT Rineka Cipta

Esen Ersoy. (2013). The effects of problem-based learning method in higher education on creative thinking: Education Faculty, Primary Mathematics Education Department Izmir, Turkey

Fitria Hidayati. (2010). Pengembangan Perangkat Pembelajaran Berorientasi Model Pembelajarn Berdasarkan masalah Pada mata Pelajaran Ipa Pokok Bahasan Sumber daya Alam. Surabaya: Tesis Magister Pendidikan, Unesa

Thiagarajan, S.D.,Semmel, S. \& Semmel, M.L. (1974) Instruction development for training teacher of exceptional children. A Source Book Bloomington: center for innovation on teaching the handica 